\title{
A Pragma-stylistic Analysis of John 3:16
}

\author{
Samuel Ayodele Dada ${ }^{1}$ \\ ${ }^{1}$ Department of English, Ekiti State University, Ado-Ekiti, Negeria \\ Correspondence: Samuel Ayodele Dada, Department of English, Ekiti State University, Ado-Ekiti, Negeria. \\ E-mail: samuelayodele2002@yahoo.com
}

Received: June 16, 2012

doi:10.5539/ijel.v2n5p85
Accepted: July 27, 2012 Online Published: September 26, 2012

URL: http://dx.doi.org/10.5539/ijel.v2n5p85

\begin{abstract}
The data for this study was extracted from the quarterly edition of Our Daily Bread (December 2007, January, February 2008) owing to its graphological layout. The aim of the study is to examine how a major stylistic meaning inducing technique in text composition manifests at the graphological level. John 3:16 in this devotional edition had been re-arranged by Anne Cetas to carry a lot of stylistic significance. The graphological study of this text featured the use of gothic printed letters, re-arrangement (verse paragraph), capitalization, and punctuation marks. Gothic printed and capitalization were graphically fussed together to coin VALENTINE out of this verse of the Scripture. Speech acts, presupposition, inference, implicature and mutual contextual beliefs (MCBs) were used to interpret the meaning of the text.

The present analysis has widened the scope of knowledge in the area of stylistics and even that of pragmatics. The graphic representation of John 3:16 and the obvious images contained in it are a clear testimony to the fact that stylistics study and practice could be more than an academic gymnastics. The study validates the thesis which states that both style/form and context contribute in equal measure to any knowledge gained in the course of reading a text.
\end{abstract}

Keywords: pragmatics, stylistics, graphology, context, valentine

\section{Introduction}

John 3:16 is the world's greatest promise and it states thus:

For God so loved the world that he gave his only begotten Son,

that whoever believeth in him should not perish, but have

everlasting life.

Ordinarily, there is nothing stylistically attractive or even significant in this verse of the scriptures either as stated in the foregoing or even as stated in the Bible, the very book containing this wonderful promise of God to the world. In other words, whenever the verse is stated prosaically as done above, there is little or nothing therein to analyse stylistically. Although biblical texts may not be popular, no doubt, such texts still form part of literature and even what could be analysed stylistically.

Indeed, if literature is defined in line with Egudu (1979: 1) as "a mode or method of expression. It is not a subject that expressed something; but rather, it is the way, manner, or method in which something is said or written".

Then, literature may have as its subject matter, Law, Geography, Religion, Science or Sports. It remains literature, irrespective of its subject matter, because it is the mode of expressing the subject matter. Interestingly, verse16 of John 3 has been re-arranged for stylistic effect in the devotional booklet that will serve as our source of data in the present study.

The paper is organised in this way: Section 1.1 discusses pragmatics and stylistics while section 1.2 is on aim and objectives. Section 2 examines research methodology, while section 3 is on findings and discussion. Section 4 is the conclusion. 


\subsection{Pragmatics and Stylistics}

\subsubsection{Pragmatics}

Pragmatics is the study of meaning in context (cf. Levision, 1983; Leech, 1983). Indeed, pragmatics has been variously defined by scholars as follows:

Leech and Short (1987: 290) say that:

The pragmatic analysis of language can be broadly understood to be the investigation into that aspect of meaning which is derived not from the formal properties of words and constructions, but from the way in which utterances are used and how they relate to the context in which they are uttered.

According to Wales (1989: 365), "pragmatics is the study of language use which is concerned with the meaning of utterances rather than a grammatical sentence or proposition”. Again a more germane definition as far as this study is concerned by Yule (1996: 1) says, "pragmatics is concerned with the study of meaning as communicated by a speaker (or writer) and interpreted by a listener (or reader). A more recent definition considers pragmatics as the study of meaning of words, phrases and full sentences and that it is more concerned with the meaning that words convey when they are used or with intended speaker meaning as it is sometimes referred to.” (Wisniewski, 2007)

The various definitions above appear to be saying the same thing; thus pragmatics studies how context influences our interpretation of utterances and that the scope of pragmatics is different from that of semantics. Semantics according to Leech and Thomas (1990) deals with meaning as a dyadic relation between a form and its meaning whereas pragmatics has to do with meaning as a triadic relation-the relation that holds among the form, meaning and context. Pragmatics does not rely only on the words and sentences used (i.e. linguistic meaning) in an utterance; it also takes into account the contextual variables which impinge on meaning. Pragmatics is that aspect of linguistics which attempts to analyze how it happens that often more is communicated than what is said. Pragmatics is "a relatively newer area of linguistics than semantics consisting a cluster of approaches which cohere around the preoccupation with the contextual constraints on meaning" (Finch, 2000: 149).

Pragmatics scholars have come up with various frameworks aimed at accounting for all possible interpretations of meanings in context. Such concepts and frameworks include: speech acts, presupposition, implicature, inference, pragmatic act, mutual contextual belief (MCB's), co-operative principle (CP), face maintenance (FM), and so on. A few of these concepts will be useful in analyzing our text since the over-riding principle here is to contextualize the text in order to exhume the meaning in the mind of the writer. Speech acts, presupposition, inference, implicature and mutual contextual beliefs (MCB) are important for the interpretation of the meaning of our data here. Hence, these concepts will form part of this study.

Speech acts theory argues that when language is used, certain acts are being performed. Three types of acts which utterances can be said to perform are: a locutionary act- the act of saying something that makes sense in the language; "consisting in a combination of a phonic act (production of actual noise), a phatic act (production of certain words in a certain syntactic order), and the rhetic act (communication of a specific message)" ( Halion, 2003 in Adetunji, 2009); an illocutionary act—act of "meaning" performed through the medium of language: warning, promising, requesting, stating, and so on; and a perlocutionary act-the effect the illocutionary act has on the listener: such as misleading, persuading, convincing, and so forth. A particular illocutionary act could be successful or not. The factors that determine whether a particular illocutionary act succeeds are termed felicity conditions or appropriacy conditions.

Based on the different views of speech act theorists, all utterances constitute speech acts of one kind or another (cf. Finch, 2000). Thus, taxonomies of speech act types provided by theorists vary in details. However, one of the most widely used, which is directly relevant to our data is that proposed by Searle (1976: 10-16), with all acts divided into five main types as follows:

1) Representatives (Assertives), which commit the speaker in varying degrees to the truth of the expressed proposition. These are acts describing situations. To Mey (2001: 120) "These speech acts are assertions about a state of affairs in the world (hence they are also called 'assertives') and they carry the values 'true' or 'false'”.

2) Directives, which are attempts with varying degrees of force to get the addressee to do something. These acts direct somebody to do something. 
3) Commissives, which commit the speaker to some future course of action. According to Mey (2001: 120-121) "like directives, commissives operate a change in the world by means of creating an obligation, however, this obligation is created in the speaker, not in the hearer, as in the case of the directive".

4) Expressives, which express the psychological state of the speaker with respect to the proposition. Expressive acts simply express the feelings/inner state of the speaker.

5) Declaratives, which effect immediate changes in the institutional state of affairs. The declarative act must, however, meet the felicity conditions to be effective.

Direct speech acts presented above provide a match between sentence meanings and speaker meaning. However, indirect speech act will not be so direct. For instance, it's cold in here can be categorized as declarative in line with the foregoing, whereas, its indirect meaning is "can you close the window" (cf. Dada, 2010). The present data is explored for both direct and indirect interpretations.

In order to ensure a sharp focus and a robust decoding of the text, in addition to the pragmatic features itemized above, the Mutual Contextual Beliefs (see Bach \& Harnish, 1979) or Lawal's (2003), “Aspects of a Pragmatic Theory" were also incorporated to provide an in-depth analysis of the data. MCBs are like "presupposition" and "implicature" in that they all rely on background information. Lawal (2003: 153), says that "MCBs centre around the speaker's intention and the listener's inference". He states further that "a speech act is performed with the aim that the listener needs to put certain facts together to decode the speaker's intention". These facts, which are well-known to both interlocutors are referred to as MCBs.

Lawal's model identifies six hierarchical contexts of an utterance: linguistic, situational, psychological, social, sociological and cosmological. The linguistic context is language itself. The situational context refers to the topic of discourse plus the factors of the physical event including concrete objects, person and location. The psychological context is the background of the mood, attitudes and personal beliefs of the language user. The social context has to do with the interpersonal relations among the interlocutors. The sociological context is concerned with the socio-cultural and historical setting. The cosmological which has to do with the ultimate context covers the language user's world-view. The different contexts/competencies enunciated above form the bed-rock of this analysis.

\subsubsection{Stylistics}

Stylistics according to the Literary Dictionary cited in Osuala (2009: 12), "is a branch of modern linguistics devoted to the detailed analysis of literary style, or of the linguistic choices made by speakers and writers in non-literary contexts". Osuala (2009: 12), herself says that "it (Stylistics) is the description and analysis of the variability of linguistic forms in actual language use".

The foregoing agrees with an earlier and popular definition of stylistics by Allan, B. et al. (1988), as:

A branch of linguistics which studies the characteristics of situationally distinctive uses of languages with reference to literary language, and tries to establish principles capable of accounting for the particular choices made by individuals and social groups in their use of language.

Thus, stylistics in its simplest form studies style. “A writer's style may be regarded as an individual and creative utilization of the resources of language which his period, his chosen dialect, his genre and his purpose within it offer him" (Spencer, 1971: xii). Style according to Enkvist et al. (1971: 12) should be regarded as:

A shell surrounding a pre-existing core of thought or expression; as the choice between alternative expressions; as a set of individual characteristics; as deviations from a norm; as a set of collective characteristics; and as those relations among linguistic entities that are statable in terms of wider spans of text than the sentence.

When these six definitions of Enkvist et al are taken along with that of Spencer, it means that there is no styless language and that a stylistic idiolect exists for everybody. In addition, style, in a way, co-exists with language. Indeed, every utterance/text has a style determined by contextual probabilities.

From the foregoing, the object of stylistics is to study, criticise and expose the "tangible manifestations of style' through both bare facts (descriptive) and "interpretive judgements" (Cluett \& Kampeas, 1979). We may ask: what are these tangible manifestations of styles? Fowler (1975: 11) answers thus:

Focus on "style"... entails close attention to the surface structure of literary texts, and an assumption that phonology, syntax, everything which makes up rhetoric, are of paramount importance in determining the identity of the literary work. 


\section{Spencer (1971: xi) on his own part says:}

To view style in literature against the background of the whole range of norms which a language develops in subserving the needs of the society which uses it, is to add a perspective to stylistic study from which the examination of language in literature cannot fail to benefit.

He further adds that:

... the English-speaking student, brought up from childhood in an English language environment will have no difficulties in this respect. Certainly he will have learnt empirically a great deal about linguistic appropriateness in many different social and functional situations. He is rarely, however, able to analyse and classify these differences... Thus the development and application of institutional categories, synchronically and diachronically, may be seen as one of the tasks awaiting the student of style.

In the light of the foregoing, stylistic analysis employs a technical (or institutional) approach to the study of literature. The stylistician uses the analytic tools of the linguist in carrying out his study. Thus, stylistic analysis should be concerned with the minute details of phonological, lexical, syntactic, semantic and graphological distinctive features embedded in a given text. Again, other areas of exploit in stylistics include: wider issues of deviation from the norm, the relationship between the author and his audience, and the relationship between language and character.

Graphological analysis, the focus of the present study, is text level analysis. This is a description of the physical representation of the text-visual devices. In linguistics, the maximum or highest unit of analysis is the sentence whereas, a larger unit, the text, serves as the basis of stylistic analysis. Areas of exploits in graphological analysis include: punctuation marks, shapes of words, orders of types of sentences, nature of verse paragraphs, and foregrounding. Foregrounding has been described by Dubsky (1962: 9) as "the use of the devices of language in such a way that this use attracts attention and is perceived as uncommon, as non-automatic..." Foregrounding manifests in different forms like capitalization, asterism, underscoring, italicization, ellipsis, etc. Graphological arrangement of a text simply expresses how the intention of an author determines the form/style of a given work of art. Thus, as rightly pointed out by Lukacs (1972: 475), "it is the view of the world, the ideology... underlying a writer's work that counts. And it is the writer's attempt to reproduce this view of the world which constitutes "intention" and is the formative principle underlying the style of a given work of writing”.

According to Oladeji (2008: 80), "it is not always realized that graphological patterns often play very crucial roles in conveying the message of an English poem". He states further that "Graphological signs can be effective as or even more effective than grammatical, lexical, or semantic signposts in the process of unravelling the message of a piece of English poetic text”. Oladeji's observation serves as an impetus for the present study. His observation becomes very germane when considered along the following lines:

At the graphological level, the stylistician ascribes high prominence to form at the expense of meaning. At this level, the traditional priority given to content over form is apparently reversed, and by devoting all its attention exclusively to form, makes content dependent on form: in this case not what is said, but how it is said. Form, then, is no longer to be viewed as a non-essential decorative affix, and not just a means to an end, but an end in itself.

Evident in the foregoing is that "form embodies... intent. Intuitively or not, an author chooses his techniques according to his meaning. Spontaneous attention to form will tell the reader more about what the author is doing and what he means than a direct analysis of meaning will do..." (Moffet \& McElheny, 1966: 567).

Thus, graphology is that level of stylistic analysis that accommodates the pragmatic meaning encoded in any written text. What is more, to appreciate the connection between form and meaning, we need to consider the fact that a change in perspective is a change in meaning, in intent and in effect. These will become clear shortly as we examine the data.

\subsection{Aim and Objectives}

The main thrust of this study is to examine how a major stylistic meaning inducing technique in text compositions manifests at the graphological level. After all, many language scholars like Fowler (1971), are of the view that stylistic analysis is merely an academic exercise with little or nothing to contribute to meaning. Thus, the present analysis is out to correct this impression by providing a concrete evidence of the influence style could have on meaning. Thus, the specific objectives of the study are as follows:

(1) To understand why this peculiar style of arrangement was chosen 
(2) To systematically and objectively describe the notable stylistic features of this arrangement.

(3) To amplify the connection between Jesus and Valentine brought to the fore through this graphic representation.

It is our hope that with these objectives in mind, it would not be difficult to showcase with this graphological evidence the influence of style on meaning. The data is a unique arrangement of the Bible verse under analysis consequently, it offers a new area to concentrate efforts on.

\section{Research Methodology}

The present data was extracted from the quarterly edition of Our Daily Bread (December 2007, January, February 2008). Precisely, it was taken from the page dated February 14, Thursday, 2008. It should be observed that dating is used for paging in this booklet. Again, this verse of the Scriptures, John 3:16, was extracted from the New King James Version of The Holy Bible by Thomas Nelson, Inc. However, other Scriptural verses used here are from the King James Version of the Bible.

The present study shuns a superficial analysis of a text that can only be understood the very way it was penned by adopting a pragma-stylistic framework. Pragmatics, the contextual use of language, was incorporated in order to capture the totality of the dimensions of the meaning of the data and this happens to be our main focus in this study. The framework aims at contextualising this text within its pragmatic presuppositions as the graphological representation of this verse of the Scriptures is a context-determined phenomenon. Meanwhile, a stylistically designed text can only be interpreted pragmatically in that a semantic approach will definitely fail to capture the intended meaning of the writer which may or may not be overtly structured in the text. Besides, a semantic analysis cannot but be superficial.

This text had to be extracted from this Daily Devotional Guide because of its great stylistic significance. Besides, the promise contained in it is of relevance to the human race, regardless of religion, culture, colour and even status. It is our hope that a study of this nature will not only provide more intellectual insights into the theory of language variation and variation in usage, but that it will also enhance the frontiers of pragmatic and stylistic theories.

\section{Findings and Discussion}

The data and the analysis of this study are in sections. Section 5.1 is on data presentation while section 5.2 is on the discussion of the data.

\subsection{The Data}

The data below was sourced from Our Daily Bread (Dec. 2007, Jan., Feb. 2008 edition; Thursday Feb. 14, no pagination) owing to its graphological layout. John 3:16, in this devotional had been re-arranged by Anne Cetas to read thus:

For God so loVed the world,

That He gAve

His onLy

BegottEn

soN

That whoever

Believes In Him

Should Not perish,

But have Everlasting life.

\subsection{The Discussion}

The major symbol captured by the graphological representation of this text is figuratively called a metaphor. Valentine is here used metaphorically to compare Valentine with Jesus. Metaphor, according to Perrine (1987: 59) is a "comparison, which is implied — that is, figurative term is substituted for or identified with literal term". According to Oxford Advanced Learners Dictionary, 7th edition, metaphor is the imaginative use of a word or phrase to describe something else, to show that the two have the same qualities. We can observe how words have been graphically chosen to express two personalities and the Bible's total view of the nature of God. Thus, 
Valentine as set out and highlighted in the text has only been used in an imaginative way here to describe the attributes of Jesus.

A major stylistic meaning inducing technique in the text's composition manifests at the graphological level. The graphological arrangement of the text is used to extol the spiritual (Jesus) through the material (Valentine). That is, the theme has a religious undertone and the stylistic choice is done to praise Jesus. In the text, two personalities born with the agape type of love are the objects of representation. One is painted overtly while the other one is evident in the original meaning of that verse of Scripture.

The stylistic exploration of the theme of sacrificial love here relies much on comparison and allusion. Graphologically, the text alludes to events in the life of Valentine. It suggests a comparison between this and that of our Lord Jesus Christ. The text is actually using Valentine to make a biblical allusion to the love of Jesus for mankind, because Jesus died sacrificially on the cross of Calvary to redeem mankind from the bondage of sin.

To get a sense (i.e. pragmatic meaning) of the context of this metaphorical text it is helpful to review a few other related verses of the Scriptures. Jesus said in John 15:13 that the greatest act of love is to lay down one's life for another. This virtue is common to both Jesus and Valentine.

Sacrificial love expressed in Ephesians 5:2 entails fidelity, purity, constancy and passion no matter how imperfect we are. Valentine is a symbol of meekness and love-the very attributes of the Lord Christ being imparted to whoever believes in Him. Valentine died for his love for intending couples itching to marry just as Jesus Christ died for the Church, His bride. Valentine's kind of love for the intending couples was a sacrificial one just as the love of Christ for the world is a selfless one. The reference to Valentine in a text of this nature simply reinforces the sacrificial love of the Lord Jesus Christ for humanity. After all, Valentine is just one of the billions of souls He died for. However, the connection here is that of love unfeigned.

The choice of a modern hero for an artistic expression on love strikes a note in the literary world. The suggestion or symbolism inherent here is in the images of love and purity that the two figures are associated with. Jesus and Valentine do not belong to the same country or century, yet what they have in common is love for the other fellow irrespective of what may be their own fate in the end. Thus, the interpretation of the analogy drawn between Jesus and Valentine. Jesus and Valentine portray a selfless life of service. Jesus' other name i.e. "God is love" is symbolically represented in that of Valentine. Valentine serves as an example of all God's people/servants who radiate the love of God to their world. Valentine is used here to represent the ultimate in loving.

A few more biblical thoughts on the basis of comparison between Jesus and Valentine may still be helpful. Submission (Eph. 5:22) another Christian virtue is a matter of trusting in God more than trusting in man. Submission simply means an alignment of one's will with that of God. In other words, submission amounts to self-sacrifice. Christ loves the church and willingly sacrifices Himself for her and in like manner, Valentine loved the people he ministered to even unto death.

Again, another obvious quality evident in these two is fulfilment. From all indications, Valentine just like Jesus lived a fulfilled life regardless of his early death. Indeed, both of them were heroes in their generations to such an extent that they are both celebrated today world-wide. Jesus is celebrated at Christmas and Easter periods, whereas Valentine is celebrated on St. Valentine's Day, February 14th, each year. In addition, both of them served God faithfully. The foregoing serves as the basis for the comparison between Valentine and Jesus.

As noted already, major stylistic meaning inducing technique in this text's composition manifests at the graphological level. Our study of graphology in this text entails the use of gothic printed letters, re-arrangement (verse paragraph), capitalization, and punctuation marks.

Gothic printed letters and capitalization: These two graphological features go together here because the two were used to coin the name VALENTINE (written vertically) out of this verse of the Scriptures.

Gothic letters are bolder than other characters. These are thick and black letters. Usually used to foreground and compel attention to any printed expression to which it is applied. It kindles interest and alerts readers' consciousness to the fact that something important lies at the heart of the text to which it is applied. Capitalization like gothic writing is also used in writing to make important parts of a text stand out clearly so as to capture the attention of the reader.

The gothic printed letters have been used here for foregrounding, emphasizes and attention. That is, to draw attention to the message of love being passed across in the text. The use of gothic printed letters have also resulted into two colours of print (black and white) as far as the physical outlay of the poem is concerned. 
Capitalization is used here to create prominence with respect to the message of the text (Valentine or love unfeigned) and to capture the readers' attention. With this strategy the reader is not allowed to miss the message of the text. Other capitalized letters here include the initial letter of each line and G of God in the first line, the $\mathrm{H}$ of $\mathrm{He}$ in line 2 and the $\mathrm{H}$ of Him in line 7. Since capital letters are used to introduce sentences, then, the capitalization of initial letters here has simply conformed to the norm/convention. Again, in writing the God of the Bible who is the Almighty is always written with a capital G including all the pronouns referring to Him. Hence, there is no aberration in this text with respect to those other uses of capitalization here including the $S$ of Son.

Paragraph: The verse has been so re-arranged in verse form typical of the kind of arrangement allowed for only in poetry. Thus, the re-arrangement has created a text of a very high literary quality. Indeed, a decoder of this text needs to first of all imagine the character of Valentine and then relate it to that of Jesus. Again, this re-arrangement into verse form has resulted into a stanza of 9 lines. Ordinarily in its normal prose form in the Bible, the verse is about 3 lines.

Punctuation marks: In all, we have as punctuation marks in the text, 2 commas and 1 full stop. These two marks have been used here conventionally. Thus, they are used to separate clauses while the only full stop here marks the end of the sentence. Punctuation marks when applied appropriately do make understanding of a printed text easier as it creates both linguistic and syntactic harmony within a text. They enhance continuity and reasonable divisions into units of thought, thereby ensuring textual cohesion.

Other meaning codifying and dispensing linguistic instruments in the text include the use of cohesive devises-pronouns, conjunction and concord. Although lexical cohesion may be considered as something outside the purview of pragmatics, yet, it is still necessary to examine this here in that "pragmatics, the study of meaning in context... and Discourse Analysis, the study of the relationship between language and contexts in which it is used (McCarthy, 1990) shared an undefined frontier as this is even evident in their definitions" (Dada, 2004: 141). We now examine these three grammatical elements one by one.

Pronouns: only personal pronouns featured in this text and these are: He, His and Him; all with the initial capital $\mathrm{H}$. This is to express the fact that they are all referring to God who is the antecedent noun as contained in line1 of the text. The subsequent uses of these pronouns after the word God create cohesion within the text.

Conjunction: the two types of conjunctions available in English, co-ordinating and subordinating conjunctions are present in this text. For co-ordinate, we have but while subordinating conjunctions are: For, that. These are cohesive grammatical devices used to cement together the complex-compound sentence.

Concord: in all there are 4 clauses here with 4 main verbs: loved, gave, believe and have. It is observed that the clauses expressing God's provision (a foregone conclusion) for the world were written in the past tense whereas, the other two clauses containing God's promise to the world based on His provision were written in the present tense to capture the relevance of this promise to the present dispensation. Thus, the harmony displayed in the use of tense.

Finally, in this section we present the other aspects of the pragmatic meaning of this text based on Searle's (1976) and Lawal's (2003), model of pragmatics.

The speech act types manifested by the text under analysis are the declarative act and the directive act. The declarative part of the text is: For God so love the world that He gave His only begotten Son. The defining characteristic of this act is that it is used to sat something and make it so, e.g. "I hereby declare the election null and void". A declarative act must, however, meet the felicity condition to be effective. Observe that expressions in this category can be prefixed with "I declare that" e.g. I declare that God loved the world that He gave His only begotten Son. Meanwhile, only God can perform the kind of action contained in this statement since He is the only being that is omnipotent. We have classified this utterance as declarative since it manifestly declares something.

The second part of the text: that whoever believes in Him should not perish, but have everlasting life; is a directive act. Directive acts try to get the hearer to act in such a way as to fulfil what is represented by the propositional content of locution. This type of act places responsibility on the hearer. Such utterances are out to advise, admonish, beg, ask, forbid, instruct, order, permit, request, require, suggest, urge or warn. Thus, the part (b) of the text under study is out to advise, admonish, urge, request, require, suggest, instruct and warn. 


\subsubsection{Declarative \& Expressive}

\section{Illocutionary acts}

a). Direct illocutionary act: Part "a" of this text is an "assertive" act of "stating”. The "b” part of this text is a "directive act" which requires action from the hearers.

b). Indirect illocutionary act: The indirect illocutionary force of this utterance is that of invitation to embrace the gift of God. Hence, this is an indirect "directive act". The expression has a persuasive function since the intention of the writer is to persuade the reader. Meanwhile, due to graphological presentation here, except the pragmatic presupposition of the text is applied, the structure may be considered of no semantic consequence.

\subsubsection{Contexts/Competencies}

a). Linguistic: This is a complex-compound structure that requires only basic competence in English grammar. The structure contains four clauses which is the characteristic of most complex-compound sentences.

b). Situational: The topic of discourse here is the love of God for the world. The world (i.e. human race) is the focus of the utterance. Son, is used here to refer to Jesus Christ who died to ransom the world and this information is part of the common background existing between the speaker and the hearer. 1John 4:14 says the Son is the Saviour of the world. 1John 5:13 "believing in the Son of God is necessary for us to inherit eternal life". 1John 4:10 God "sent His Son to be the propitiation for our sins, thus, knowledge of the Bible which is the only book that tells of God's great love for us is an essential ingredient of perfect understanding."

c). Psychological: The writer of this text who has the task of making sure his write-up makes impact on the audience is simply acting this out with his choice of arrangement of the words in the text so much so that the word Valentine was created in the process. This stylistic technique no doubt carries positive connotations. With this arrangement, the writer succeeded in turning a factual speech into "a logical one so as to oppose readers" former beliefs and to motivate action in them. In other words, if you cannot identify with God's love through Jesus you can at least identify with Valentine who popularized the agape kind of love. This, at least, is a good step in the right direction.

d). Social: A relationship of the lover and the beloved exists here. Pronominalisation is a linguistic means used to show relationship between the addressee and the addresser. Thus, to create audience involvement the text uses "whoever" to refer to the addressee just to ensure that every reader identifies himself/herself with the message.

e). Socio-cultural: The text consists of simple sentences which are however directed to the hearer/reader through the use of the pronoun "whoever". In other words, God's love is not restricted to any one nation, race or culture or even to any spiritual elite.

World here may also include all of creation (see Rom. 8: 19-22, Col. 1: 20).

f). The Cosmological Context: The totality of the cosmological context (i.e. world-view) which has produced the text is a universalist, anti-racist conviction which the text writer deploys all his intellectual, linguistic and creative resources to defend and promote.

\section{Conclusion}

The present analysis has widened the scope of knowledge in the area of stylistics and even that of pragmatics. The graphic representation of John 3:16 and the obvious images contained in it are clear testimony to the fact that stylistics study and practice could be more than an academic gymnastics. The foregoing validates the thesis which states that both style/form and content contribute in equal measure to any knowledge gained in the course of reading a text. Indeed, the pragma-stylistic configurations of a text as presented above are to be considered for an effective interpretation of a text.

Stylistics as evident from the text requires great imagination of the writer to enable him write one thing in terms of another and also for the reader to get the intended meaning of the authors. Indeed, cases of allegories such as this are left to the reader to perceive or interpret by identifying the fact and making the necessary correlation. Thus, interpretation of allegorical texts relies heavily on the imaginative power of both the writer and the reader.

\section{References}

Adeniji, A. (2009). The pragmatics of voices in the Non-Marxist Plays of Femi Osofisan: The Case of Farewell to a Cannibal Rage. In Odebunmi, A., Arua, E. A., \& Arimi, S. (Eds.), Language Gender and Politics: A Festschrift for Yisa Kehinde Yusuf (pp. 392-407). Lagos: Concept Publications Ltd. 
Adetunji, A. (2009). Acts in the Second Inaugural Addresses of Nigeria's President Olusegun Obasanjo and America's President George Bush. In Odebunmi, A., Arua, E. A., \& Arimi, S. (Eds.), Language Gender and Politics: A Festschrift for Yisa Kehinde Yusuf (pp. 275-296). Lagos: Concept Publications Ltd.

Allan, B., \& et al. (Eds.). (1988). The Fontana Dictionary of Modern Thoughts (2nd ed.). London: Fontana.

Bach, K., \& Harnish, R. (1979). Linguistic Communication and Speech Acts. Cambridge: M.I.T. Press.

Cluett, R., \& Kampeas, R. (1979). Glossly Speaking. Toronto: Discourse Associates Ltd.

Dada, S. A. (2004). Introduction to Pragmatics. In Bamisaye, T. O. (Ed.), An Intergrated Study in Language and Society (Vol. 1, pp. 141-169). Lagos: Majab Publishers.

Dada, S. A. (2010). A Speech Act Analysis of Slogans of Telecoms Companies in Nigeria. In Kuupole, D. D., \& Bariki, I. (Eds.), Applied Social Dimensions of Language Use and Teaching in West Africa. Festschrift in Honour of Professor Tunde Ajiboye (pp. 52-62). Ghana: The University Press.

Dubsky, J. (1962). Standard Language and Poetic Language. In P. I. Garvin (Ed.), A Prague School Readers on Aesthetics, Literary Structure and Style (p. 9). Washington: Georgetown University Press.

Egudu, R. N. (1979). The Study of Poetry. Ibadan: University Press Ltd.

Enkvist, N. E., Spencer, J., \& Gregory, M. J. (1971). Linguistics and Style. Oxford: Oxford University Press.

Finch, G. (2000). Linguistic Terms and Concepts. New York: Palgrave Macmillan.

Fowler, R. (1976). The Language of Literature: Some Linguistic Contributions to Criticism. London: Routledge and Kegan Paul Ltd.

Friday-Otun, J. O. (2004). A Pragma-stylistic Analysis of Proverbs 26, Verses 4 \& 5. Ilorin Journal of Language and Literature, 1(6), 37-51.

Lawal, A. (2003). Pragmatics in Stylistics: A Speech Act Analysis of Soyinka's Telephone Conversation. In A. Lawal (Ed.), Stylistics in Theory and Practice (pp. 150-173). Ilorin: Paragon Books.

Leech, G. (1983). The Principles of Pragmatics. London: Longman.

Leech, G., \& J. Thomas. (1990). Langauage Meaning and Context: Pragmatics. In Collin, N. E. (Ed.), An Encyclopedia of Language (pp. 173-201). London: Routledge.

Lukacs, G. (1972). The Ideology of Modernism. In David Lodge (Ed.), 20th Century Literary Criticism: A Reader (pp. 474-488). London: Longman.

McCarthy, M. (1990). Discourse Analysis for Language Teachers. Cambridge: Cambridge University Press.

Mey, J. L. (2001). Pragmatics. An Introduction. USA: Blackwell Publishing.

Moffett, J., \& McElheny, R. K. (Ed.). (1966). Point of View: An Anthology of Short Stories. New York: The New American.

Oladeji, N. (2008). A Practical Stylistic Guide for the Nigerian Undergraduate Students of English Poetry. In O. L. Oyegoke (Ed.), Undergraduate Text on English Languageand Literature (pp. 78-95). Ibadan: Yori Books.

Osuala, P. C. (2009). A Semio-stylistic Analysis of the Currency notes of Nigeria and the United States of America. B.A. Long Essay, Department of English, Redeemer’s University, Ogun State.

Perrine, L. (1987). Sound and Sense: An Introduction to Poetry. London: Harcourt Brace Jovenovish Publishers.

Searle, J. R. (1976). The Classification of Illocutionary Acts. Language and Society, 5, 1-23. http://dx.doi.org/10.1017/S0047404500006837

Spencer, J. (1971). Introduction. In Enkvist, N. E., Spencer, J., \& Gregory, M. J. (Eds.), Linguistics and Style (pp. vii-xii). London: Oxford University Press.

Wales, K. (1989). A Dictionary of Stylistics. London: Longman.

Wisniewski, K. (2007). Pragmatics. Retrieved September 10, 2012, from http://www.tlumaczenia-angielski.info/linguistics/pragmatics.htm

Yule, G. (1996). Pragmatics. London: Oxford University Press. 